\title{
Pulling Together or Pulling Apart? Solidarity in the Post-Crisis UK
}

\author{
Tom Montgomery, Simone Baglioni, Olga Biosca, \\ and Maria Grasso
}

\section{INTRODUCTION}

The importance of solidarity can hardly be underestimated in contemporary Britain. The UK has weathered the financial crisis, witnessed the impact of austerity in public services and local economies, and experienced a highly divisive European referendum which has not only polarised British society and transformed the political landscape but also reconfigured relations with European neighbours and reopened internal divisions regarding the constitutional future of the UK (Temple and Grasso 2017). In this context, this chapter seeks to uncover the reality of solidarity in British society by analysing data from a novel survey data set examining various aspects of solidarity-including its correlate political behaviours in support of various beneficiary groups residing within and outside one's country. Our aim is to analyse the various dimensions of solidarity as well as which

T. Montgomery $(\bowtie) \bullet$ S. Baglioni $\bullet$ O. Biosca

Yunus Centre, Glasgow Caledonian University, Glasgow, UK

M. Grasso

Department of Politics, University of Sheffield, Sheffield, UK

(C) The Author(s) 2018

C. Lahusen, M. Grasso (eds.), Solidarity in Europe,

Palgrave Studies in European Political Sociology,

https://doi.org/10.1007/978-3-319-73335-7_4 
factors lead to its political behavioural practice. In what follows, we analyse which groups in society are the most solidaristic and which groups can rely on others' solidarity the most. First, however we analyse the relevant literature that has addressed these theoretical questions in the past.

The concept of solidarity has been long established in social science and has been the subject of key works (Durkheim 1893) including those focused on the UK context (Thompson 1963). While the introduction to this volume has offered a conceptual discussion, this chapter focuses on examining the practical behavioural manifestations of solidarity understood as a range of actions that people deploy in support of potentially vulnerable groups and individuals, namely, the disabled, the unemployed, and migrants and refugees. Our focus on solidarity in terms of practiced forms of active engagement in favour of vulnerable groups has political connotations. This is because such activities imply either claims in support of these groups in relation to civil or human rights and social policy entitlements vis-à-vis the state or because they challenge negligence or refusal to support such rights and entitlements that have been promised through policy but still lack actual enforcement.

Furthermore, the political connotations of our conceptualization of solidarity are related to two highly contentious issues: (a) how to fund the enforcement of rights and (b) whether the same level of access to the implementation of rights should be granted on an equal basis to all those in need. In other words, our understanding of solidarity implies answering politically relevant questions such as should the costs of implementing rights be equally shared among members of the community or should those directly benefiting from implementation bear the costs? And if the costs should be pooled from general taxation-as happens in most Western European welfare states - should public funds provide universal support equally across groups in need, or should solidarity be made conditional upon meeting given criteria?

These are fundamental questions at the heart of democratic debate today. The ultimate contemporary relevance of these questions today further illustrates how solidarity lies at the heart of a contentious domain, given that individuals and groups have different and sometimes opposing opinions about whether we should and to what extent help others in need. Indeed this question lies at the very heart of the fundamental ideological debate between left and right which has been at core of democratic politics at least since the French Revolution. Whereas the post-war social democratic consensus was characterised by strong support for universalist 
welfare states across Western Europe, the neo-liberal break of the late 1970s challenged the idea that society should provide safety nets to help vulnerable groups and insisted on the principles of self-interested market competition as incentivising individuals to contribute towards society (English et al. 2016; Grasso et al. 2017; Temple et al. 2016). Other than ideological factors, earlier studies have also suggested that the willingness of people to express solidarity with others is mediated by several other important factors, some of which pertain to perceived characteristics of those being helped and their ascribed deservingness, while others are linked to the characteristics of those providing help or with the socioeconomic and political characteristics of the contexts where people live.

Among those factors considered to be influential for the willingness of people to help others are the perceptions of:

1. the degree of control those in need have over their own 'neediness' (the less responsible for their situation they are perceived to be, the more inclined are people to help);

2. their level of need (people with greater needs are seen as more deserving);

3. their identity (cultural proximity facilitates deservingness);

4. their attitude (conforming to 'standards' fosters solidarity), and

5. reciprocity (people that have 'earned' support through their contribution to the community and its pool of funds in earlier periods are more deserving of being helped). (van Oorschot 2006: 26)

Moreover, earlier studies have also argued that a disposition towards solidarity depends upon individual characteristics such as age, level of education, socio-economic position and political-ideological orientation, as well as levels of life satisfaction (Dunn et al. 2014; Grasso 2013, 2016). These studies had shown that the solidarity of older, less well-educated, less well-off, less-satisfied, and more right-wing individuals is more conditional on the beneficiaries meeting precise criteria with in particular the perceived degree of control that beneficiaries have over their needs as well their identity being the most powerful 'conditionality' drivers (ibid.). The reasons behind such a high degree of conditionality among older, less well-educated, less well-off, less-satisfied, and more right-wing people have been shown to cluster around two main factors: personal interests and ideology. People that feel themselves to be in a relatively more insecure social position consider the solidarity provided to those in need as 
providing competition for their own needs, thus diminishing their support for solidarity. Other aspects preventing solidarity from developing or making it more conditional are linked to ideas people have of 'otherness' such as, for example, a negative attitude towards migrants preventing solidarity for asylum seekers or refugees and more generally a lack of trust in others and narrow views of social embeddedness (inhibiting wider social solidarity) (van Oorschot 2006).

Nevertheless, research reveals that the willingness of people to help others is also influenced by the type of country they live in: welfare regimes play a crucial role in institutionalising solidarity and are relevant in fostering or mitigating social solidarity. For example, residual welfare regimes tend to increase conditionality as fewer resources are available to meet a range of needs, and also national policies and policy discourses should be considered since one would imagine a national policy environment supporting solidaristic attitudes will mitigate claims for conditionality among its citizens, while a general policy discourse emphasising prejudices against those in need would create the opposite-a more greatly conditional attitude (Blekesaune and Quadagno 2003; van Oorschot and Arts 2005).

To summarise this discussion, solidarity implies a dynamic, interactive process of constant renegotiation of social citizenship boundaries, which is per se in essence a political phenomenon. In this chapter we are interested in understanding how people living in the UK are part of this process, the extent to which solidaristic activities are practised, whether solidarity activities are germane to a conditionality approach, and also if solidarity is practised at different levels between people living in the various geographic areas of the country, and finally whether such differences could be explained by taking into consideration both individual characteristics and local contexts. The chapter unfolds as follows. We next present our hypotheses and then move on to illustrate data and methods, and finally we discuss our results and their wider implications.

\section{Hypotheses}

Building on the extant literature, we explore solidarity through the prism of five main hypotheses related to either the individual or contextual levels of analysis. Starting with the latter, we focus on the role that national policies and discourses play in generating solidaristic (or anti-solidaristic) attitudes and hypothesise that solidarity will be unevenly distributed across 
the constituent nations of the UK. We expect that it will be more vibrant in those areas which have a tradition of progressive and solidaristic approaches to social issues and where the effects of the Conservative-led government anti-statist, neo-liberal policies have been mitigated by devolved authorities with a different policy orientation (viz. Northern Ireland and Scotland). Secondly, we also hypothesise that in such different contexts, we will find a varying degree of conditionality attached to solidarity: thus we will have a lower degree of conditionality in the more progressive and 'policy solidaristic' constituent nations (Northern Ireland and Scotland) than in others (England and Wales).

To understand why we hypothesise that solidarity can diverge across the constituent nations of the UK requires an appreciation of the historical context and the political cultures which have developed in devolved nations. Firstly, in terms of Scotland, we can see that there is a longstanding argument in the literature on the development of 'policy autonomy' (Midwinter et al. 1991) or indeed a distinctive political culture (Kellas 1989). The debate regarding a distinctively Scottish political culture and its extent is ongoing and to some extent has been integrated into the seemingly unresolved question of the future of Scotland in the UK following the 'No' vote which took place in the 2014 Scottish independence referendum (Torrance 2013; Macwhirter 2014) and the rise of the SNP as the dominant force in Scottish politics (Johns and Mitchell 2016). Another dimension to that debate is whether or not the Scottish sociopolitical context can be considered more egalitarian than its counterparts in England (Mooney and Poole 2004).

Northern Ireland can also be seen to have a distinctive political context where the divisions between the nationalist and unionist communities continue to be a fault line through society. Nevertheless, following the common experience of 'the Troubles' which saw a great loss of life over a period of 30 years, the peace process (Mallie and McKittrick 1996) cemented by the Good Friday Agreement (Tonge 2000; Bew 2007) has developed alongside an emphasis on equality (McCrudden 1998) between the previously conflicting communities and the centrality of consociationalism (McGarry and O'Leary 2004) in overcoming divisions (Lijphart 2012). Therefore, to some extent we can hypothesise that the proliferation of discourses, legislation, and indeed the very governance of Northern Ireland (Tonge 2002) may contribute towards the construction of a more fertile environment for solidarity to be practised. 
Considering the individual level, following earlier studies, we hypothesise that younger, more educated, more socially connected people (Giugni and Grasso 2015; Grasso and Giugni 2016) and people with a higher level of satisfaction with their overall life will be more likely to take action in favour of disabled people, the unemployed, migrants and refugees. In addition to these considerations, we are also controlling for the exposure of individuals to specific media discourses building from research that has identified newspaper readership as a factor which shapes attitudes towards each of our three vulnerable groups (Golding and Middleton 1982; Greenslade 2005; Briant et al. 2011). Consistent with this literature, we hypothesise that reading more right-wing and prejudicial newspapers (e.g. tabloids) will likely be associated with lower inclination to solidarity in comparison to progressive newspaper readership. Moreover, building upon the findings of earlier studies that 'identity sharing' is a factor facilitating solidarity, we also control for direct exposure to vulnerability and hypothesise that those who are more directly exposed to vulnerability through being in one of our vulnerable categories (disabled, unemployed, migrants, or refugees) will likely be more solidaristic than those who are not. In the following section, we briefly present our data set, variables, and methods.

\section{DATA}

This chapter uses cross-sectional data from an original survey, described in greater detail in the introduction of this book conducted in the context of the TransSOL European collaborative project in the winter months of $2016 / 2017$ to examine solidarity at the individual level in eight European countries. Information was gathered on citizens' solidarity practices, attitudes and behaviours, as well as on socio-demographic characteristics, political attitudes, and cultural orientations. In this study, we use the UK-based sample with age, gender, region, and education quotas matched for nationally representative statistics of 2083 UK-based survey respondents. Survey weights were included in all analyses.

The variables used for this analysis are presented in Table 4.1 and further details of the original survey questions and any relevant recodings are provided in Appendix. The dependent variables of solidarity practices used indicate if respondents have supported, in the last 12 months, the rights of particular people/groups through various forms of political actions including more contentious as well as more 
Table 4.1 Descriptive statistics

\begin{tabular}{lccc}
\hline & Mean & Std. dev. & Obs. \\
\hline Supported rights of people/groups in own country & 38.4 & 0.49 & 2083 \\
Supported rights of people/groups in other countries within & 18.9 & 0.39 & 2083 \\
the EU & & & \\
Supported rights of people/groups outside Europe & 25.4 & 0.44 & 2083 \\
Supported the rights of refugees/asylum seekers & 21.7 & 0.41 & 2083 \\
Supported the rights of the unemployed & 18.8 & 0.39 & 2083 \\
Supported disability rights & 34.6 & 0.48 & 2083 \\
Age & 47.32 & 16.58 & 2083 \\
Female & 51.3 & 0.50 & 2083 \\
Higher education & 29.9 & 0.47 & 2083 \\
Intermediate education & 33.8 & 0.47 & 2083 \\
Unemployed & 5.1 & 0.22 & 2083 \\
Disabled & 17.3 & 0.38 & 2044 \\
Born in UK & 90.2 & 0.30 & 2083 \\
Daily Mail & 21.2 & 0.41 & 2083 \\
The Sun & 12.2 & 0.33 & 2083 \\
The Times & 9.5 & 0.29 & 2083 \\
The Guardian & 10.6 & 0.31 & 2083 \\
Daily Mirror & 8.0 & 0.27 & 2083 \\
Other newspapers & 15.4 & 0.36 & 2083 \\
Met friends at least once a month & 73.9 & 0.44 & 2083 \\
Life satisfaction & 6.45 & 2.15 & 2032 \\
Scotland & 8.5 & 0.28 & 2083 \\
Wales & 4.8 & 0.21 & 2083 \\
Northern Ireland & 2.8 & 0.16 & 2083 \\
\hline
\end{tabular}

Note: Age is measured in years. Life satisfaction is measured by a 10-point Likert-style response scale where a higher number represents higher life satisfaction. The remainder of the variables are percentages. Base category for education variable is lower education. Base category for newspaper variable is 'Not reading any newspaper regularly (3+ days a week).' Base category for constituent country variable is England

conventional types: attended a march, protest, or demonstration; donated money; donated time; bought or refused to buy products; engaged as passive member of an organisation (pay cheque membership); engaged as an active member of an organisation (volunteering in an organisation). A further question asked was if respondents participated in any of the above actions: through a process of recoding, binary variables were created that took the value of one if respondents reported participating in any of these solidarity actions and zero if they said otherwise. These binary variables resulted in six dependent variables for this 
analysis indicating if individuals said they had been involved in any of the listed political activities (1) in support of the rights of people/groups in one's own country, (2) in support of the rights of people/groups in other countries within the EU, (3) in support of the rights of people/ groups outside Europe, (4) in support of the rights of refugees/asylum seekers, (5) in support of the rights of unemployed people, and finally (6) in support of the rights of disabled persons.

\section{Geographies of Solidarity: Findings from the Constituent Nations and Regions OF THE UK}

Our analysis begins by considering if the data supports our hypothesis concerning the expectation of diverse degrees of solidarity between the constituent nations of the UK. We do so by comparing answers to three questions which asked respondents whether, in the last 12 months, they had engaged in various political actions in support of the rights of people living in the UK, living in Europe, and those living outside of Europe. Findings in Table 4.2 reveal supportive evidence for our hypothesis about divergent patterns of solidarity across the UK constituent nations: although with small margins, our respondents from Scotland and Northern Ireland report stronger solidarity than people living in England or Wales. This is true not only of solidarity activities undertaken for UK-based beneficiaries but also with respect to beneficiaries based elsewhere. With the caveat of their being small numbers in our sub-UK level sample-which are however

Table 4.2 Solidarity practices in different geographical areas by constituent country in the UK

\begin{tabular}{lrccc}
\hline Country & $N$ & $\begin{array}{c}\text { Supported rights in } \\
\text { own country (\%) }\end{array}$ & $\begin{array}{l}\text { Supported rights in } \\
\text { Europe (\%) }\end{array}$ & $\begin{array}{l}\text { Supported rights } \\
\text { outside Europe (\%) }\end{array}$ \\
\hline England & 1761 & 38.0 & 18.7 & 25.1 \\
Scotland & 177 & $44.7^{*}$ & 20.9 & 29.6 \\
Wales & 97 & 38.2 & 14.5 & 20.8 \\
Northern & 48 & 31.2 & 25.1 & 27.0 \\
Ireland & & & 18.9 & 25.4 \\
Total UK & 2083 & 38.4 & & \\
\hline
\end{tabular}

Notes: ${ }^{* *} p<0.01,{ }^{* *} p<0.05,{ }^{*} p<0.1$. For definition of the variables, see Table 4.1 
representative of the different demographic weights of the UK constituent nations-our findings provide a unique contribution to the debate on divergence between the constituent nations of the UK by focusing on practices of solidarity, and our results do suggest that there is indeed a divergence between these contexts within the UK.

Our findings also reveal the uneven distribution of solidarity practices in terms of the groups towards which support is directed (still holding across the constituent nations of the UK). Contrary to our hypothesis, in fact, the vibrancy of solidarity practices is not equal across people in need: some groups appear more 'deserving' of help than others. Our results indicate that for the most part, the practice of solidarity is aimed at protecting the rights of those within the UK. Further, longitudinal research could reveal if this inward-looking tendency is a constant within British society or whether these feelings have intensified towards UK beneficiaries following the financial crisis and the ensuing austerity measures. Regardless, our analysis shows that the focus is primarily on practising solidarity within the UK. In turn, this may be reflecting a narrowing of the scope of solidarity during periods of financial downturn and the retrenchment of public services, or alternatively this trend could predate the current crisis. Indeed, we can see that in terms of transnational solidarity, practices are more geared towards supporting those who are outside of Europe rather than our European neighbours. We can speculate that the issue of prioritising deservingness may have a role to play here. In other words, those engaged in solidarity practices may consider that those outside of Europe require the most assistance. We can further speculate that this may be driven by responses to emergencies such as the Syrian refugee crisis.

Still concerning the hypothesis about the existence of a 'solidarity ladder' where different categories of people and groups occupy different positions, our findings appear to confirm earlier studies (van Oorschot $2000,2006)$. Table 4.3 reveals an uneven distribution of solidarity across the three vulnerable groups: people with disabilities, unemployed people, and migrants/refugees. The group which attracts the greatest degree of solidarity are people with disabilities. In fact, disabled people are the group with the greatest degree of solidaristic support across all four constituent nations of the UK. However, again we also find an uneven distribution with the highest levels of solidarity to be found in Northern Ireland and Scotland. 
Table 4.3 Solidarity practices with vulnerable groups (refugees, unemployed, disabled) by constituent country in the UK

\begin{tabular}{lrccc}
\hline Country & $N$ & Support refugees (\%) & Support unemployed (\%) & Support disabled (\%) \\
\hline England & 1761 & $20.8^{*}$ & $18.0^{* *}$ & $33.2^{* * *}$ \\
Scotland & 177 & $28.6^{*}$ & $27.5^{* * *}$ & $44.9^{* * *}$ \\
Wales & 97 & 18.5 & 16.5 & 33.9 \\
Northern & 48 & $30.9^{*}$ & 18.7 & $48.0^{* *}$ \\
Ireland & & & & 34.6 \\
Total UK & 2083 & 22.7 & 18.8 & \\
\hline
\end{tabular}

Notes: ${ }^{* *} p<0.01,{ }^{* *} p<0.05,{ }^{*} p<0.1$. For definition of the variables, see Table 4.1

Our findings that solidarity is more targeted towards people with disabilities may indicate that in the UK this group is deemed the most deserving out of our three vulnerable groups, although this heavier distribution of solidarity towards disabled people deserves a more nuanced analysis. For example, we can speculate that this could be driven by a more paternalistic attitude towards people with disabilities. The perception of people with disabilities as being somehow helpless or indeed tragic figures who require support from others has been strongly opposed by disability campaigners who since the 1970s in the UK have sought to contrast those narratives of disabled people as victims. This is illustrated, for example, through those social movements and activists who adopt the 'social model of disability' which understands the challenges faced by people with disabilities as being constructed by a 'disabling society' and rejects deservingness but instead demands equal treatment as citizens (Oliver et al. 2012). Therefore, although our findings make for positive reading in terms of the solidarity targeted towards people with disabilities, our analysis requires a much more cautious approach and fine-grained understanding of the perceptions of disabled people which may be driving this solidarity especially when considered alongside the solidarity professed for the other vulnerable groups.

Our findings outlined in Table 4.3 reveal that the group with the next highest share of solidarity practices are refugees and that these practices are again unevenly distributed across the constituent nations of the UK. We can see how the support for refugees is highest in Northern Ireland and Scotland with a visible gap between them and England and Wales. From previous research, we can see that there has been, for a 
considerable time, a proliferation of negative policy discourses aimed at those seeking refuge and asylum in the UK and indeed at migrants more generally (Sales 2002; Statham and Geddes 2006; Squire 2008). Our findings confirm that there is certainly a section of the population which stands in stark contrast to the 'racist public' thesis, and their practices point towards a current of solidarity suggested by extant research (Squire 2011). Nevertheless, there has been, across governments of different political orientations, a drive towards policies which are far more focused on border control than solidarity when it comes to refugees arriving in the UK (Squire 2016). Given that immigration and asylum policy is reserved to Westminster control and there are few avenues for devolved administrations to pursue alternative approaches, this perhaps only leaves space for rhetorical divergence.

Moreover, our findings reveal that among our three groups, it is unemployed people in the UK who are supported by the lowest number of solidarity participation practices. Any analysis of why the unemployed are the least supported group should be caveated by the fact that most support for the unemployed in the UK has traditionally been delivered by the welfare state through support with basic subsistence such as Jobseeker's Allowance (JSA) and with the cost of rent through Housing Benefit (HB). It is, however, worth noting that both of these benefits have been at the centre of a welfare reform agenda pursued in the aftermath of the financial crisis by the Conservative and Liberal Democrat coalition government elected in 2010 and articulated through their policy document Welfare in the Twenty-First Century which highlighted concerns of a 'culture of worklessness' in the UK. Moreover, ever since the break with the post-war consensus initiated by Margaret Thatcher and followed through by both Conservative and New Labour prime ministers, support for unemployed people has been under attack with those out of work increasingly characterised as lazy and as undeserving of public support. Rather than unemployment being understood as a social, political, and structural problem emerging from the limits of capitalist production, it has now been fully recast as an individual-level problem resulting from the deficient personalities of certain people. Indeed, such policies reflected this ideological process of transformation of poverty and unemployment from market failure to personal failure (Wiggan 2012). Indeed this has been shown as a consistently strong trope in austerity Britain, even impervious to contrary evidence (MacDonald et al. 2014a, b), and offers some context as to why 
the unemployed are the group viewed as least deserving among the three vulnerable groups we have focused upon here.

Our findings in Table 4.3 also reveal that there is variation in solidarity practices towards the unemployed across the UK, with a much greater distribution of solidarity evident in Scotland than anywhere else in the UK. These findings in Scotland support our hypothesis of policy divergence across the constituent nations across the UK and add weight to the argument that Scotland has a more social democratic outlook which in turn may lead to a greater degree of solidarity with those out of work, particularly given the common experience of deindustrialization in highdensity population centres such as in the Central Belt. Nevertheless, we should be cautious in our approach to understanding this greater tendency towards solidarity practices in Scotland as extant research suggests an alignment between Scotland and England in social attitudes in terms of what are the causes of unemployment (Sinclair et al. 2009).

Therefore, to summarise the key results from this section, our findings reveal, as shown in both Tables 4.2 and 4.3, the existence of a hierarchy of solidarity in the UK. Firstly, British people express more solidarity towards those living in the UK (Table 4.2), and this confirms earlier research pointing towards the role that 'identity' plays in issues of deservingness. Indeed, people have been shown to be more inclined to adopt a solidaristic attitude towards those that are perceived as more similar or sharing identity-related features with them. Considering variations across the vulnerable groups, solidarity towards the unemployed is the least strong of the three and may suggest that policy discourses and media narratives which have stigmatised the unemployed may be cutting through to British society. Moreover, it could be that the British public in general views unemployed people as the most responsible for their condition compared to people with disabilities and refugees/asylum seekers. In the middle of this hierarchy are refugees, who we may have expected to be the primary target for solidarity activities among our three groups, not only because of the sense of urgency regarding the Syrian refugee crisis but also because our earlier findings suggested that transnational forms of solidarity are more geared towards those outside of Europe.

The group at the apex of our hierarchy, namely, the disabled, can be understood to occupy that position for two main reasons. On the one hand, it may be that they have been a group more visible in terms of the impact of austerity upon them, not only through the reassessments of 
Fig. 4.1 The hierarchy of solidarity in the UK

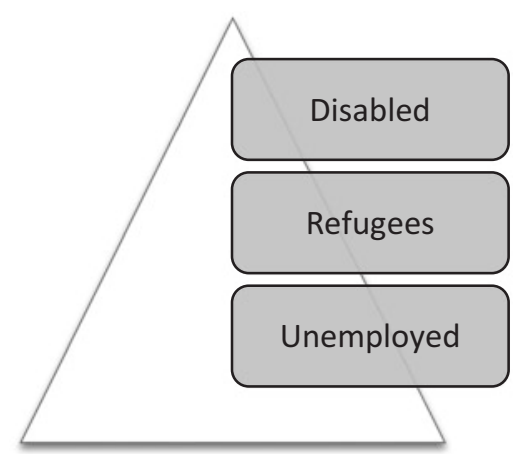

eligibility for welfare support such as Employment and Support Allowance ${ }^{1}$ (ESA) but also policies such as the 'bedroom tax'. ${ }^{2}$ On the other hand, the high degree of solidarity directed towards people with disabilities could be understood as being reflective of long-standing stereotypes seeing them as victims of their illness rather than equal citizens who have been at the sharp end of austerity measures. Therefore, the 'hierarchy of solidarity', found in our results and illustrated in Fig. 4.1 serves to remind us of the uneven distribution of solidarity towards vulnerable groups and it requires a more careful understanding of the factors which may be driving solidarity such as the continued attempts by the UK government since the onset of the crisis and the ensuing austerity measures to distinguish between deserving and undeserving groups.

\section{Results FOR THE INDIVIDUAL-LEVEL VARIABLES}

As we shall discover, our findings suggest that although the hierarchy of solidarity outlined earlier may provide a broad understanding of the distribution of solidarity across each group, a more nuanced analysis reveals the fluidity of these hierarchies when considering a range of different variables. In order to test our hypotheses, we used a logit model (Table 4.4) to analyse the relationship between our dependent variables of solidarity practice across different geographies (inside the UK, outside the UK but inside the EU, and outside the EU) and vulnerabilities (refugee/asylum seekers, the unemployed, and the disabled) and number of independent variables relevant to our underlying hypotheses. As discussed in the introductory and data sections, these include socio-demographic 
Table 4.4 Solidarity practices to support the rights in different areas and groups

\begin{tabular}{|c|c|c|c|c|c|c|}
\hline & $\begin{array}{l}\text { Inside } \\
\text { the UK }\end{array}$ & $\begin{array}{l}\text { In the EU, } \\
\text { outside UK }\end{array}$ & $\begin{array}{l}\text { Outside } \\
\text { the EU }\end{array}$ & $\begin{array}{l}\text { Refugees } \\
\text { and/or } \\
\text { asylum } \\
\text { seekers }\end{array}$ & Unemployed & Disabled \\
\hline Age & $\begin{array}{l}-0.03 \\
(0.02)\end{array}$ & $\begin{array}{l}-0.08^{* * *} \\
(0.02)\end{array}$ & $\begin{array}{l}-0.06 * * * \\
(0.02)\end{array}$ & $\begin{array}{l}-0.11 * * * \\
(0.02)\end{array}$ & $\begin{array}{l}-0.08^{* * *} \\
(0.02)\end{array}$ & $\begin{array}{l}-0.04^{*} \\
(0.02)\end{array}$ \\
\hline Age squared & $\begin{array}{l}0.00 \\
(0.00)\end{array}$ & $\begin{array}{l}0.00^{*} \\
(0.00)\end{array}$ & $\begin{array}{l}0.00 * * \\
(0.00)\end{array}$ & $\begin{array}{l}0.00 * * * \\
(0.00)\end{array}$ & $\begin{array}{l}0.00 * * \\
(0.00)\end{array}$ & $\begin{array}{l}0.00 \\
(0.00)\end{array}$ \\
\hline Female & $\begin{array}{l}-0.18^{*} \\
(0.10)\end{array}$ & $\begin{array}{l}-0.14 \\
(0.13)\end{array}$ & $\begin{array}{l}-0.24^{* *} \\
(0.12)\end{array}$ & $\begin{array}{l}0.04 \\
(0.12)\end{array}$ & $\begin{array}{l}-0.44^{* * *} \\
(0.13)\end{array}$ & $\begin{array}{l}-0.13 \\
(0.10)\end{array}$ \\
\hline \multicolumn{7}{|c|}{ Education (ref.: low education) } \\
\hline $\begin{array}{l}\text { Intermediate } \\
\text { education }\end{array}$ & $\begin{array}{l}0.09 \\
(0.12)\end{array}$ & $\begin{array}{l}0.05 \\
(0.17)\end{array}$ & $\begin{array}{l}0.12 \\
(0.14)\end{array}$ & $\begin{array}{l}0.25 \\
(0.16)\end{array}$ & $\begin{array}{l}0.09 \\
(0.16)\end{array}$ & $\begin{array}{l}0.07 \\
(0.12)\end{array}$ \\
\hline $\begin{array}{l}\text { Higher } \\
\text { education }\end{array}$ & $\begin{array}{l}0.32 * * \\
(0.13)\end{array}$ & $\begin{array}{l}0.33^{*} \\
(0.17)\end{array}$ & $\begin{array}{l}0.69^{* * *} \\
(0.15)\end{array}$ & $\begin{array}{l}0.74 * * * \\
(0.16)\end{array}$ & $\begin{array}{l}0.35^{* *} \\
(0.16)\end{array}$ & $\begin{array}{l}0.23^{*} \\
(0.13)\end{array}$ \\
\hline Unemployed & $\begin{array}{l}0.10 \\
(0.25)\end{array}$ & $\begin{array}{l}0.45 \\
(0.28)\end{array}$ & $\begin{array}{l}0.23 \\
(0.27)\end{array}$ & $\begin{array}{l}0.38 \\
(0.29)\end{array}$ & $\begin{array}{l}0.21 \\
(0.30)\end{array}$ & $\begin{array}{l}0.32 \\
(0.25)\end{array}$ \\
\hline Disabled & $\begin{array}{l}0.55^{* * *} \\
(0.13)\end{array}$ & $\begin{array}{l}0.31^{*} \\
(0.17)\end{array}$ & $\begin{array}{l}0.47^{* * *} \\
(0.15)\end{array}$ & $\begin{array}{l}0.34^{* *} \\
(0.16)\end{array}$ & $\begin{array}{l}0.54^{* * *} \\
(0.16)\end{array}$ & $\begin{array}{l}0.84^{* * *} \\
(0.13)\end{array}$ \\
\hline Born in UK & $\begin{array}{l}-0.10 \\
(0.17)\end{array}$ & $\begin{array}{l}-0.43^{* *} \\
(0.19)\end{array}$ & $\begin{array}{l}-0.62 * * * \\
(0.17)\end{array}$ & $\begin{array}{l}-0.14 \\
(0.19)\end{array}$ & $\begin{array}{l}-0.20 \\
(0.20)\end{array}$ & $\begin{array}{l}-0.35^{* *} \\
(0.17)\end{array}$ \\
\hline \multicolumn{7}{|c|}{ Newspaper readership } \\
\hline Daily Mail & $\begin{array}{l}0.18 \\
(0.12)\end{array}$ & $\begin{array}{l}0.14 \\
(0.15)\end{array}$ & $\begin{array}{l}0.13 \\
(0.13)\end{array}$ & $\begin{array}{l}0.01 \\
(0.14)\end{array}$ & $\begin{array}{l}0.27^{*} \\
(0.15)\end{array}$ & $\begin{array}{l}0.29 * * \\
(0.12)\end{array}$ \\
\hline The Sun & $\begin{array}{l}0.23 \\
(0.15)\end{array}$ & $\begin{array}{l}0.56^{\star \star *} \\
(0.18)\end{array}$ & $\begin{array}{l}0.43^{* * *} \\
(0.17)\end{array}$ & $\begin{array}{l}0.44^{* *} \\
(0.18)\end{array}$ & $\begin{array}{l}0.69^{* * *} \\
(0.17)\end{array}$ & $\begin{array}{l}0.53^{* * *} \\
(0.15)\end{array}$ \\
\hline The Times & $\begin{array}{l}0.67 * * * \\
(0.17)\end{array}$ & $\begin{array}{l}1.00 * * * \\
(0.18)\end{array}$ & $\begin{array}{l}0.73^{* * *} \\
(0.17)\end{array}$ & $\begin{array}{l}0.92 * * * \\
(0.18)\end{array}$ & $\begin{array}{l}1.11^{* * *} \\
(0.18)\end{array}$ & $\begin{array}{l}0.78 * * * \\
(0.17)\end{array}$ \\
\hline The Guardian & $\begin{array}{l}1.09 * * * \\
(0.17)\end{array}$ & $\begin{array}{l}0.95^{* * *} \\
(0.17)\end{array}$ & $\begin{array}{l}0.91 * * * \\
(0.16)\end{array}$ & $\begin{array}{l}1.10 * * * \\
(0.17)\end{array}$ & $\begin{array}{l}0.60 * * * \\
(0.18)\end{array}$ & $\begin{array}{l}0.45^{* * *} \\
(0.16)\end{array}$ \\
\hline Daily Mirror & $\begin{array}{l}0.37 * * \\
(0.18)\end{array}$ & $\begin{array}{l}0.41 * \\
(0.22)\end{array}$ & $\begin{array}{l}0.43^{* *} \\
(0.20)\end{array}$ & $\begin{array}{l}0.66^{* * *} \\
(0.21)\end{array}$ & $\begin{array}{l}0.62 * * * \\
(0.21)\end{array}$ & $\begin{array}{l}0.36^{*} \\
(0.19)\end{array}$ \\
\hline $\begin{array}{l}\text { Other } \\
\text { newspapers }\end{array}$ & $\begin{array}{l}0.10 \\
(0.14)\end{array}$ & $\begin{array}{l}-0.14 \\
(0.19)\end{array}$ & $\begin{array}{l}-0.02 \\
(0.16)\end{array}$ & $\begin{array}{l}-0.27 \\
(0.18)\end{array}$ & $\begin{array}{l}-0.09 \\
(0.18)\end{array}$ & $\begin{array}{l}-0.25^{*} \\
(0.14)\end{array}$ \\
\hline $\begin{array}{l}\text { Met friends } \\
\text { once month }\end{array}$ & $\begin{array}{l}0.40 * * * \\
(0.12)\end{array}$ & $\begin{array}{l}0.25 \\
(0.16)\end{array}$ & $\begin{array}{l}0.23^{*} \\
(0.14)\end{array}$ & $\begin{array}{l}0.25^{*} \\
(0.15)\end{array}$ & $\begin{array}{l}0.25 \\
(0.16)\end{array}$ & $\begin{array}{l}0.31 \text { *** } \\
(0.12)\end{array}$ \\
\hline Life satisfaction & $\begin{array}{l}0.06 * * * \\
(0.03)\end{array}$ & $\begin{array}{l}0.03 \\
(0.03)\end{array}$ & $\begin{array}{l}0.04 \\
(0.03)\end{array}$ & $\begin{array}{l}0.10 * * * \\
(0.03)\end{array}$ & $\begin{array}{l}0.09 * * * \\
(0.03)\end{array}$ & $\begin{array}{l}0.08 * * * \\
(0.03)\end{array}$ \\
\hline \multicolumn{7}{|c|}{ Region (ref.: England) } \\
\hline Scotland & $\begin{array}{l}0.33^{*} \\
(0.17)\end{array}$ & $\begin{array}{l}0.28 \\
(0.22)\end{array}$ & $\begin{array}{l}0.31^{*} \\
(0.19)\end{array}$ & $\begin{array}{l}0.56^{* * *} \\
(0.20)\end{array}$ & $\begin{array}{l}0.73 * * * \\
(0.20)\end{array}$ & $\begin{array}{l}0.60 * * * \\
(0.17)\end{array}$ \\
\hline Wales & $\begin{array}{l}0.13 \\
(0.23)\end{array}$ & $\begin{array}{l}-0.04 \\
(0.32)\end{array}$ & $\begin{array}{l}-0.07 \\
(0.27)\end{array}$ & $\begin{array}{l}0.05 \\
(0.29)\end{array}$ & $\begin{array}{l}0.16 \\
(0.30)\end{array}$ & $\begin{array}{l}0.22 \\
(0.23)\end{array}$ \\
\hline
\end{tabular}


Table 4.4 (continued)

\begin{tabular}{cllllll}
\hline & $\begin{array}{l}\text { Inside } \\
\text { the UK }\end{array}$ & $\begin{array}{l}\text { In the EU, Outside } \\
\text { outside UK the EU }\end{array}$ & $\begin{array}{l}\text { Refugees } \\
\text { and/or } \\
\text { asylum } \\
\text { seekers }\end{array}$ & Unemployed & Disabled \\
\hline Northern & -0.30 & 0.42 & 0.02 & $0.65^{*}$ & 0.01 & $0.52^{*}$ \\
Ireland & $(0.34)$ & $(0.39)$ & $(0.37)$ & $(0.36)$ & $(0.42)$ & $(0.32)$ \\
Constant & -0.76 & 0.48 & -0.02 & -0.28 & -0.51 & -0.63 \\
Pseudo $R^{2}$ & $(0.50)$ & $(0.63)$ & $(0.56)$ & $(0.59)$ & $(0.62)$ & $(0.51)$ \\
$N$ & 0.07 & 0.16 & 0.11 & 0.13 & 0.12 & 0.07 \\
\hline
\end{tabular}

Notes: Coefficients of the logit model are shown. Standard errors are in parentheses. ${ }^{* * *} p<0.01$, ${ }^{* *} p<0.05,{ }^{*} p<0.1$. For definition of the variables, see Table 4.1

variables (e.g. age, education), but we also look at the significance of being born in the UK, which we regard as an important variable given the importance that identity issues have on solidarity and deservingness, as discussed earlier. We also examine variables encompassing the vulnerability of the respondent (e.g. disability or unemployment) to gauge if exposure to such vulnerability at a time of crisis and austerity has an effect on the practice of solidarity by these groups; social embeddedness has also been a long-standing focus of literature on solidarity (van Oorschot 2006) as well as on political participation (Putnam 2001; Maloney et al. 2000; Hall 1999). Life satisfaction is a variable deployed to reveal whether practices of solidarity are the purview of those who feel happy with their quality of life; as anticipated in the hypotheses, we will also control for how readership of different types of newspapers influence solidarity attitudes (we hypothesise that readers of more conservative and populist-oriented newspapers will be less inclined towards solidarity); and as per one of our key hypotheses, we look at the residency of the respondent (e.g. living in Scotland, Wales, Northern Ireland) to identify divergences in the practice of solidarity across the constituent nations of the UK where devolution has empowered assemblies and parliaments. The results from the regressions we conducted are set out below.

When analysing our individual-level variables, our hypothesis was that the practice of solidarity would depend on a range of factors, including a higher level of education. Our education hypothesis builds upon established research on solidarity but also on political participation and civic engagement that education provides the necessary 
resources for an individual to become engaged in societal and political issues (Verba et al. 1995). Furthermore, we hypothesised that those with a higher level of education had more material resources to engage in solidarity. When examining our findings in Table 4.4, we can see that our hypothesis is confirmed by a significant and positive relationship between being disposed towards actions of solidarity and being in higher education. Consequently, we find confirmation of our hypothesis that those with higher education are better resourced to engage in practices of solidarity than those with fewer resources (Grasso 2017).

A classic socio-demographic variable-age-presents us with interesting results confirming our hypothesis. What can be seen in Table 4.4 is that age is negative and significantly associated with solidarity with each of the vulnerable groups as well as each geographic area with the sole exception of those inside the UK. Therefore the younger you are in the UK, the more predisposed you are towards engaging in practices of solidarity. The implications of these findings can be seen to some extent in the vote which took place in the $2016 \mathrm{EU}$ referendum for the UK to leave the EU, where older voters were more predisposed towards voting leave (Hobolt 2016). Nevertheless, our findings suggest that the negative relationship between solidarity and age extends to anyone who is 'other' than within the UK. These findings also shed some light on how policies which are restrictive towards refugees, austerity policies affecting the disabled, and policies characterised by sanctions and compulsion towards the unemployed can be sustained given the higher propensity for older people to turn out at elections in the UK and reinforce the urgency for more young people to become politically engaged before any change in direction could take place (Gardiner 2016).

Our findings regarding social embeddedness support our hypothesis that the practice of solidarity depends on exposure to social networks and social interaction. In this case, social embeddedness is defined as 'meeting socially with friends during the last month' and, as we can see in Table 4.4, is positively and significantly associated, from a geographic perspective, with offering solidarity to those within the UK and those outside the EU as well as a similar relationship in terms of solidarity with refugees and the disabled. The importance of social capital in building social cohesion is well established in the literature (Putnam 2001; Li et al. 2005), and our findings in the UK resonate with these works. In terms of implications for policymaking, another of our findings may be acutely relevant towards 
understanding how to develop solidarity in the UK. Given the significant association between higher life satisfaction and solidarity with others within the UK, as well as each of our vulnerable groups, suggests that policies geared towards individual well-being may have a positive impact in terms of engendering solidarity in the UK.

When considering our results in terms of gender, what we can see in Table 4.4 is the negative and significant relationship between being female and practising solidarity, specifically with groups within the UK and those outside the EU as well as there being a similar relationship with solidarity and the unemployed. Further still, more qualitative research may unpack the specificities of the gender dimension of solidarity (or in this case nonsolidarity). Extant research suggests that women have been at the forefront of the austerity cuts and as a consequence may have few resources, in either money or time, to divert to solidarity practices (O'Hara 2014). In addition to this, it is important to note that despite steps closer towards equality, women continue to perform many of the caregiving tasks across UK households, not only in terms of looking after children but also caring for sick or disabled members of the family, which research suggests has an impact on retaining employment (Carmichael et al. 2008).

One hypothesis underpinning our analysis of the practice of solidarity is the exposure to information and, despite the rise of online media, newspaper readers continue to be courted by policymakers in the UK and thus retain an important place in shaping and reflecting policy discourses and the political agenda. Firstly, we discover a positive and significant relationship between reading The Times, The Guardian, or the Daily Mirror and practices of solidarity in comparison to not reading any newspapers. However, Table 4.4 presents a result falsifying our hypothesis regarding the influence of tabloid readership on the lack of solidarity: there is a positive and significant association between reading The Sun and the practice of solidarity with each vulnerable group, except for those within the UK. Moreover, reading the Daily Mail is positively associated with solidarity towards the unemployed and the disabled. These results are surprising given the conservative leaning history of both publications; consequently, there is perhaps some scope to consider that although content of course matters, our findings suggest the difference between reading and not reading a newspaper appears to be the key determinant in mobilising solidarity in the UK. Given the migration of much political debate in recent years from the analogue world of newspapers to the 
digital world of social media, with research indicating that even newspapers themselves are utilising social media as a resource for political news gathering (Broersma and Graham 2012), we can speculate, as an avenue for further research, that it is through online media that we may find associations between specific media preferences and asymmetric distributions of solidarity towards vulnerable groups.

Concerning our hypothesis of direct exposure or experience of vulnerability, in Table 4.4 we see that that the disabled are positively and significantly associated with solidarity practices across each of the geographic areas and all other vulnerable groups. The exposure of disabled people to multidimensional forms of discrimination and inequalities may provide a cross-societal insight into the hardships suffered by different groups (EHRC 2017). We can speculate that the importance of rights-based discourses among disabled people's organisations and in a similar way with disability charities in the UK may create the conditions for intersectionality between the disabled and other groups seeking rights, protection, and indeed solidarity. Moreover, the 'social model of disability' (Oliver et al. 2012) embraced by a number of disabled people's organisations has frequently recognised injustices and inequalities in society which impact upon groups other than the disabled. Subsequently, our findings regarding the disposition of the disabled towards supporting other groups may open an avenue to consider an alternative explanation as to why the disabled are viewed as most deserving, as outlined earlier in this chapter, but instead of paternalistic attitudes through a sense of reciprocity. This may seem a less convincing argument for explaining attitudes towards the disabled in the UK, but our findings require us to consider it in the scope of our interpretation.

Still on the individual-level characteristics, Table 4.4 confirms our hypothesis about level of satisfaction with life as a factor being positively related with solidarity: the happier about her/his life conditions a person is, the more she/he will likely be ready to support less fortunate people and vice versa (Borgonovi 2008). Therefore, life satisfaction acts as a proaltruism factor that discourages people from considering those in need as potential competitors for services and state support.

Looking at the other findings of our regressions in Table 4.4, we can see that the divergences of solidarity between the different constituent nations in the UK outlined earlier in this chapter are confirmed by our regressions. Our results indicate that living in Scotland, in comparison to 
living in England, is positively and significantly associated with expressing greater solidarity with others within the UK and those living outside the EU. Moreover, we can see that living in Scotland compared to England is also positively and significantly associated with solidarity towards each of our three vulnerable groups. Furthermore, our results indicate that living in Northern Ireland in comparison to England also renders a significant and positive association with undertaking solidarity practices towards refugees and the disabled. Therefore, our regressions do provide further evidence of a significant divergence in the disposition of individuals to engage in practices of solidarity. Consequently, we can hypothesise that these divergences will stay in place should devolved administrations remain sensitive to the support evident within their constituent nations and have the potential to grow wider should policies and discourses at the Westminster level increasingly contrast with these solidaristic dispositions and become more antagonistic towards vulnerable groups. As Keating (2003) points out, the use of values can be central in the construction of identity, and he argues that territorial solidarity was more effective in confronting Thatcherism than class solidarity. Therefore, should a post-Brexit Britain continue to travel down a road of welfare retrenchment and discourses distinguishing between the deserving and undeserving, there may be irreversible constitutional consequences for the UK. This is particularly relevant for Scotland where research has indicated the potential for social policy divergence to open opportunities to reconfigure solidarity and shared values around a (Scottish) national identity of 'difference' rather than the solidarity of a retrenched British welfare state (McEwen 2002) and where the Scottish government has, post-Brexit, called for a second referendum on independence.

Finally, we need to consider another finding relating to the role of identity in solidarity. In fact, being born in the UK is another variable which yields the type of findings which have strong implications for the composition of solidarity in the UK. As we can see in Table 4.4, there is a significant and negative relationship between those individuals who are born in the UK and solidarity with those groups from outside the UK, whether in the EU or not. Such findings suggest that solidarity among those who are British born tends to be inward looking and that policies towards refugees that emphasise border control rather than welcoming asylum do have a constituency in the UK. Thus, our findings perhaps represent the other side of the coin when we are 
considering those initiatives which are geared towards offering sanctuary to those seeking asylum. Perhaps somewhat surprisingly however, among that same group-those born in the UK-there is also a significant and negative association with solidarity with the disabled. This stands in sharp contrast to the hierarchy of solidarity we set out earlier in this chapter, but we can speculate that those born in the UK may be more likely to view support for the disabled as the remit of the welfare state. If this is the explanation, then it is concerning because as austerity measures have affected the benefits which disabled people have been entitled to, public services have also come under budgetary pressures and, as a consequence, there is the potential for the hardship experienced by disabled people to be somewhat overlooked by those born in the UK who believe that the welfare state would act as a safety net, reinforced by the stigma experienced by disabled benefit claimants who retreat from social circles in order to avoid 'revealing' that they are claiming benefits (Garthwaite 2015). A further consideration based on our finding is that those who are not born in the UK may be more solidaristic towards the disabled and we can speculate that, particularly given the discourses of border control in the UK, those not born in the UK may empathise with others who are cast as 'outsiders' by discourses and policy.

\section{Conclusions}

In this chapter we have sought to uncover how solidarity, through active engagement in support of specific groups of people in need, is practised in contemporary Britain. What the analysis of our data reveals is that solidarity is unevenly distributed in terms of geography and the vulnerabilities of different groups. Our findings resonate to some extent with existing research (van Oorschot 2006), suggesting deep-rooted patterns of deservingness and established hierarchies across Europe when considering solidarity with vulnerable groups such as the disabled, refugees, and the unemployed. As such, our findings offer a further contribution to this body of literature, but they also present a contemporary and novel insight into how solidarity is distributed across the constituent nations of the UK, where we have observed some divergence, but also how policies and discourses in post-crisis, post-Brexit Britain may be shaping attitudes towards the three vulnerable groups and thus play a 
role in constructing the hierarchy of solidarity we have set out in Fig. 4.1. Nevertheless, when we factor in our independent variables, a more complex picture emerges, one that does not disprove the existence of our hierarchy of solidarity but suggests that the hierarchy is less static than we may imagine and is made more malleable when we introduce our independent variables. The findings which then emerge point towards talking not only of hierarchies of solidarity but fluid hierarchies of solidarity which can change shape and reflect a more diverse distribution of solidarity than our initial findings suggest. This fluidity is underpinned by the asymmetric significance of our variables which reveal that access to information (through newspaper readership), exposure to vulnerability (through disability), the experience of higher education, and the interaction with others through social networks are key determinants of solidarity in the UK. As a consequence, we can confirm our hypothesis that the distribution of solidarity is determined by the exposure of an individual to vulnerabilities similar to those experienced by those categories, to their degree of exposure to opportunities of socialisation and information sharing (social networks), as well as to their interest in societal and political issues.

In terms of the distribution of solidarity practices across the UK, our findings confirm our hypothesis of the existence of sub-national divergences. Such divergences suggest a more nuanced understanding of the variegated impact of discourses of deservingness and their commensurate policies beyond traditional welfare regime analysis. This opens the possibility for a renewed research agenda on regional and sub-national distinctiveness across Europe in terms of social solidarity. Any divergences will be relevant to developing a more fine-grained analysis across each context, but perhaps such an approach, as we have outlined in this chapter, is currently most relevant in the UK where such divergences may prove critical in determining the constitutional future of the British state, particularly given our findings that solidarity is most evident in two constituent nations which voted to remain part of the EU: Scotland where there are renewed calls by the SNP for another independence referendum and Northern Ireland where Sinn Fein have called for a poll on a united Ireland. Therefore, understanding solidarity towards vulnerable groups offers an insight not only into the nature of solidarity in contemporary Britain but also provides an indication of the challenges faced by the UK government elected in June 2017. 


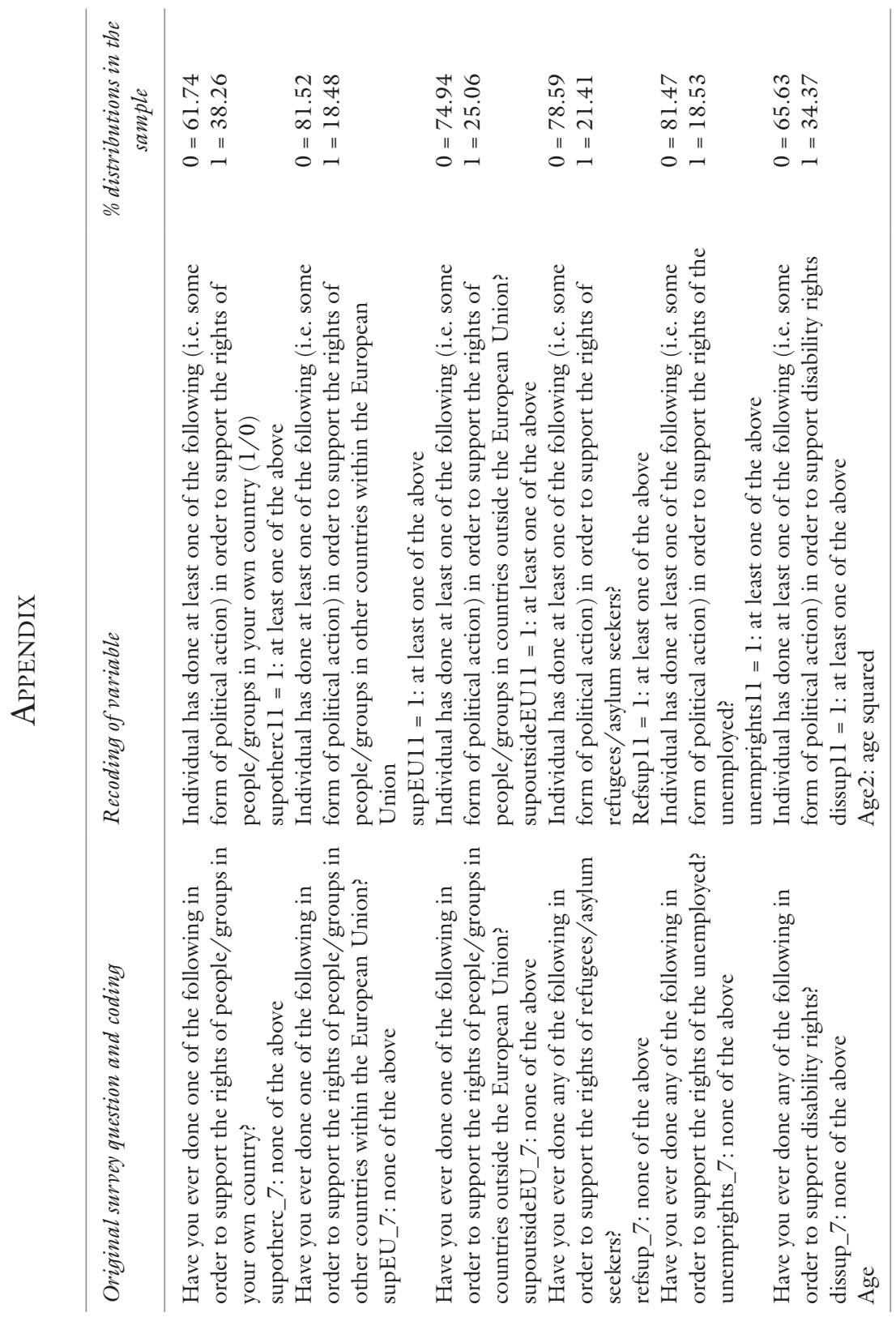




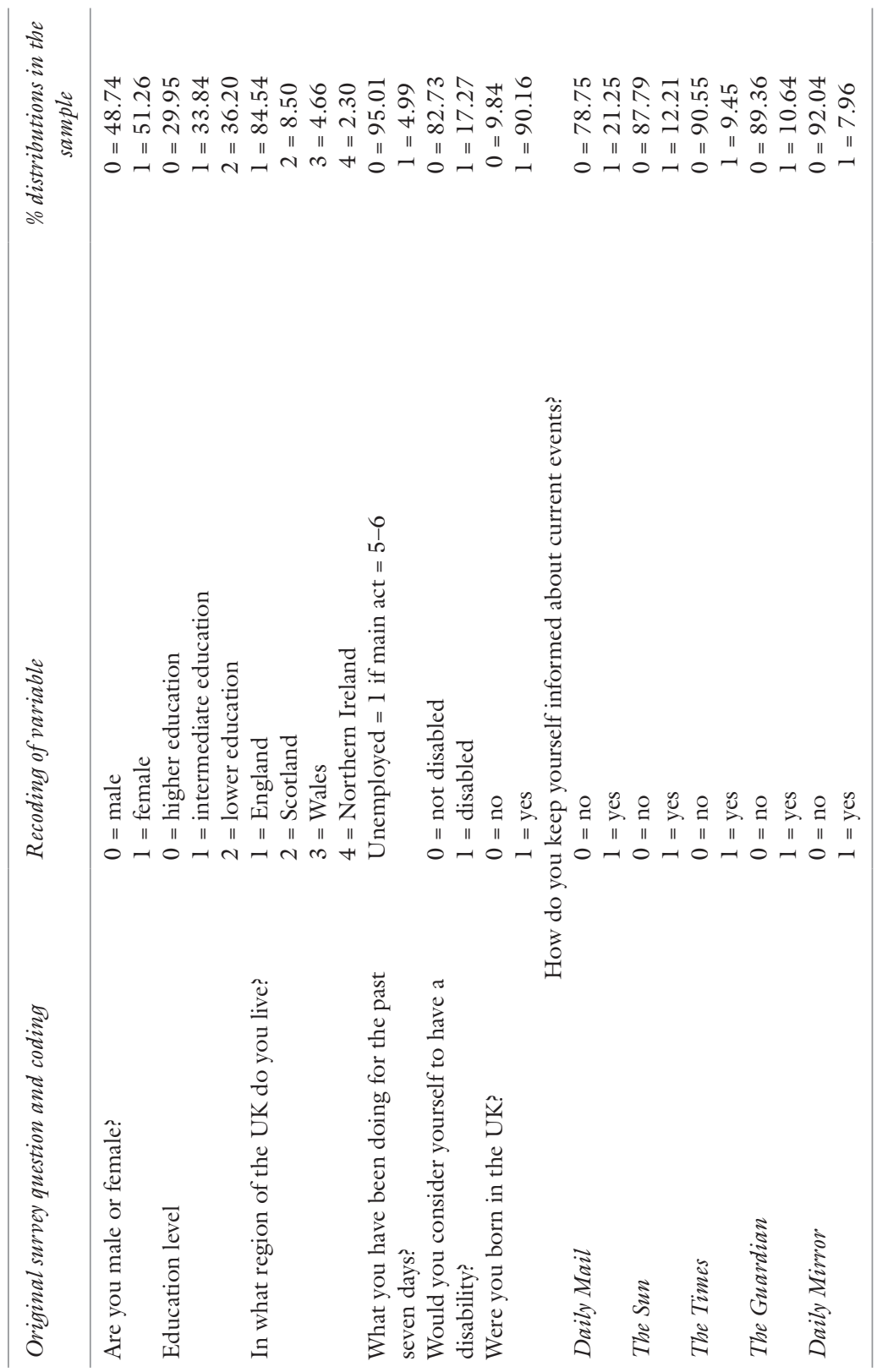


96 T. MONTGOMERY ET AL.

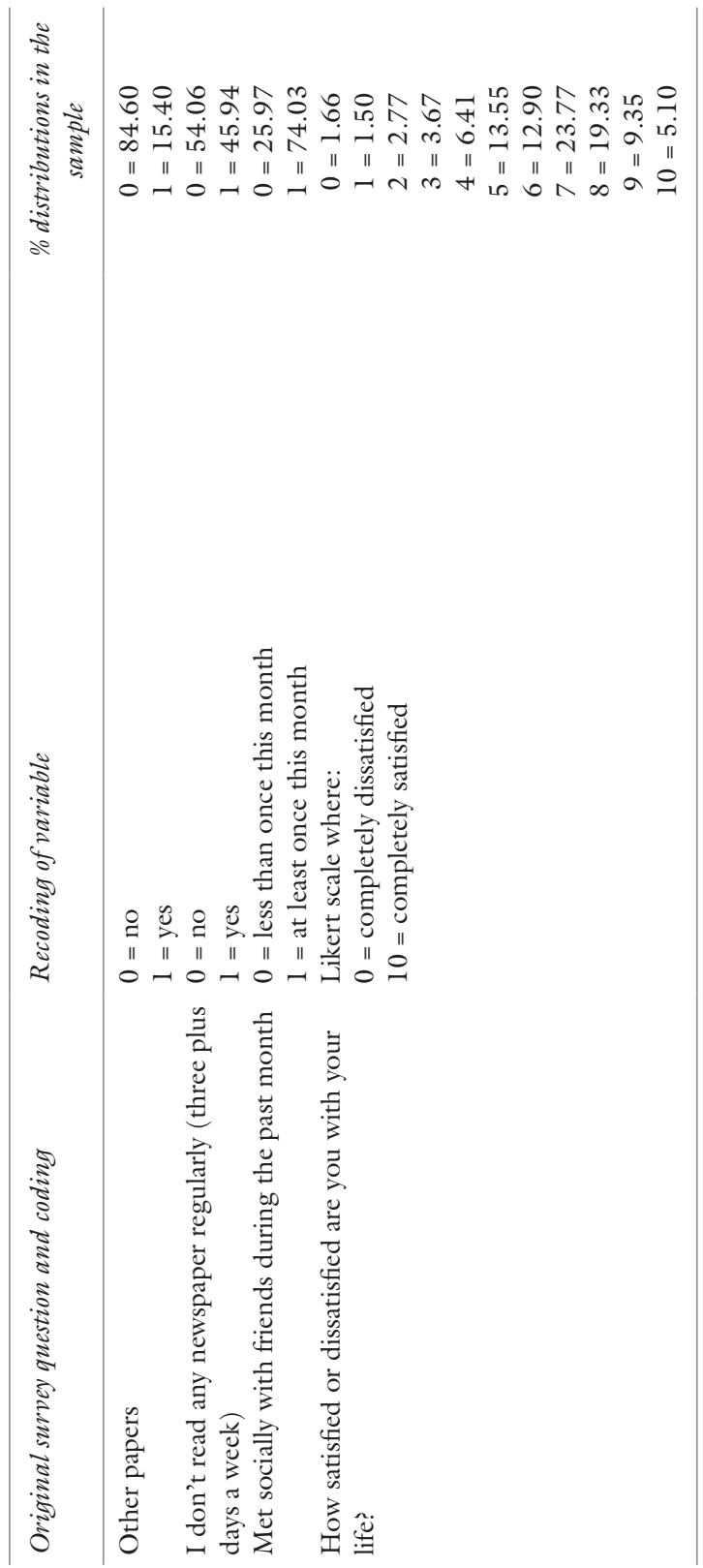




\section{Notes}

1. This involved a national reassessment process that was piloted in 2010 and rolled out in 2011 with the objective of reassessing all claimants for ESA (formerly known as Incapacity Benefit) through a 'Work Capability Assessment' by Spring 2014 which resulted in 750,000 assessments being conducted in 2013 alone (see Baumberg et al. 2015).

2. A reduction applied to the Housing Benefit of social housing tenants ( $14 \%$ if they have one spare bedroom and $25 \%$ if they have two or more spare bedrooms) that disproportionately affected disabled people despite measures introduced ('discretionary housing payments') to mitigate the impact (See Gibb 2015; Wilcox 2014).

\section{REFERENCES}

Baumberg, B., Warren, J., Garthwaite, K., \& Bambra, C. (2015). Rethinking The Work Capability Assessment. London: Demos.

Bew, P. (2007). The Making and Remaking of the Good Friday Agreement. Dublin, Ireland: Liffey Press.

Blekesaune, M., \& Quadagno, J. (2003). Public Attitudes Toward Welfare State Policies: A Comparative Analysis of 24 Nations. European Sociological Review, $19(5), 415-427$.

Borgonovi, F. (2008). Doing Well by Doing Good. The Relationship Between Formal Volunteering and Self-Reported Health and Happiness. Social Science \& Medicine, 66(11), 2321-2334.

Briant, E., Watson, N., \& Philo, G. (2011). Bad News for Disabled People: How the Newspapers Are Reporting Disability. Project Report. Strathclyde Centre for Disability Research and Glasgow Media Unit, University of Glasgow, Glasgow, UK.

Broersma, M., \& Graham, T. (2012). Social Media as Beat: Tweets as a News Source During the 2010 British and Dutch Elections. Journalism Practice, 6(3), 403-419.

Carmichael, F., Hulme, C., Sheppard, S., \& Connell, G. (2008). Work-Life Imbalance: Informal Care and Paid Employment in the UK. Feminist Economics, 14(2), 3-35.

Dunn, A., Grasso, M. T., \& Saunders, C. (2014). Unemployment and Attitudes to Work: Asking the 'Right' Question. Work, Employment, and Society, 28(6), 904-925.

Durkheim, E. (1893 [2014]). The Division of Labour in Society. Simon and Schuster.

English, P., Grasso, M. T., Buraczynska, B., Karampampas, S., \& Temple, L. (2016). Convergence on Crisis? Comparing Labour and Conservative Party 
Framing of the Economic Crisis in Britain, 2008-2014. Politics \& Policy, 44(3), $577-603$.

Equality and Human Rights Commission. (2017). Being Disabled in Britain: A Journey Less Equal.

Gardiner, L. (2016). Votey McVoteface: Understanding the Growing Turnout Gap Between the Generations. London: Resolution Foundation.

Garthwaite, K. (2015). 'Keeping Meself to Meself'-How Social Networks Can Influence Narratives of Stigma and Identity for Long-Term Sickness Benefits Recipients. Social Policy \& Administration, 49(2), 199-212.

Gibb, K. (2015). The Multiple Policy Failures of the UK Bedroom Tax. International Journal of Housing Policy, 15(2), 148-166.

Giugni, M., \& Grasso, M. T. (2015). Environmental Movements in Advanced Industrial Democracies: Heterogeneity, Transformation, and Institutionalization. Annual Review of Environment and Resources, 40, 337-361.

Golding, P., \& Middleton, S. (1982). Images of Welfare: Press and Public Attitudes to Poverty. Oxford: Robertson.

Grasso, M. T. (2013). The Differential Impact of Education on Young People's Political Activism: Comparing Italy and the United Kingdom. Comparative Sociology, 12(1), 1-30.

Grasso, M. T. (2016). Generations, Political Participation and Social Change in Western Europe. London: Routledge.

Grasso, M. T. (2017). Young People's Political Participation in Times of Crisis. In S. Pickard \& J. Bessant (Eds.), Young People Regenerating Politics in Times of Crisis. London: Palgrave Macmillan.

Grasso, M. T., \& Giugni, M. (2016). Protest Participation and Economic Crisis: The Conditioning Role of Political Opportunities. European Journal of Political Research, 55(4), 663-680.

Grasso, M. T., Farrall, S., Gray, E., Hay, C., \& Jennings, W. (2017). Thatcher's Children, Blair's Babies, Political Socialisation and Trickle-Down ValueChange: An Age, Period and Cohort Analysis. British Journal of Political Science. https://doi.org/10.1017/S0007123416000375.

Greenslade, R. (2005). Seeking Scapegoats: The Coverage of Asylum in the UK Press. Institute for Public Policy Research.

Hall, P. A. (1999). Social Capital in Britain. British Journal of Political Science, $29(3), 417-461$.

Hobolt, S. B. (2016). The Brexit Vote: A Divided Nation, a Divided Continent. Journal of European Public Policy, 23(9), 1259-1277.

Johns, R., \& Mitchell, J. (2016). Takeover: Explaining the Extraordinary Rise of the SNP. London: Biteback.

Keating, M. (2003). Social Inclusion, Devolution and Policy Divergence. The Political Quarterly, 74(4), 429-438.

Kellas, J. G. (1989). The Scottish Political System. Cambridge University Press. 
Li, Y., Pickles, A., \& Savage, M. (2005). Social Capital and Social Trust in Britain. European Sociological Review, 21(2), 109-123.

Lijphart, A. (2012). Patterns of Democracy: Government Forms and Performance in Thirty-Six Countries. Yale University Press.

MacDonald, R., Shildrick, T., \& Furlong, A. (2014a). In Search of 'Intergenerational Cultures of Worklessness': Hunting the Yeti and Shooting Zombies. Critical Social Policy, 34(2), 199-220.

MacDonald, R., Shildrick, T., \& Furlong, A. (2014b). 'Benefits Street' and the Myth of Workless Communities. Sociological Research Online, 19(3), l.

Macwhirter, I. (2014). Road to Referendum. Glasgow: Cargo Publishing.

Mallie, E., \& McKittrick, D. (1996). The Fight for Peace. London: Heinemann.

Maloney, W., Smith, G., \& Stoker, G. (2000). Social Capital and Urban Governance: Adding a More Contextualized ‘Top-Down’ Perspective. Political Studies, 48(4), 802-820.

McCrudden, C. (1998). Mainstreaming Equality in the Governance of Northern Ireland. Fordham Int'l LJ, 22, 1696.

McEwen, N. (2002). State Welfare Nationalism: The Territorial Impact of Welfare State Development in Scotland. Regional o Federal Studies, 12(1), 66-90.

McGarry, J., \& O'Leary, B. (2004). The Northern Ireland Conflict: Consociational Engagements. Oxford University Press on Demand.

Midwinter, A., Keating, M., \& Mitchell, J. (1991). Politics and Public Policy in Scotland. London: Macmillan.

Mooney, G., \& Poole, L. (2004). A Land of Milk and Honey? Social Policy in Scotland After Devolution. Critical Social Policy, 24(4), 458-483.

O'Hara, M. (2014). Austerity Bites. Policy Press.

Oliver, M., Sapey, B., \& Thomas, P. (2012). Social Work with Disabled People. Palgrave Macmillan.

van Oorschot, W. (2000). Who Should Get What, and Why? On Deservingness Criteria and the Conditionality of Solidarity Among the Public. Policy o Politics, 28(1), 33-48.

van Oorschot, W. (2006). Making the Difference in Social Europe: Deservingness Perceptions Among Citizens of European Welfare States. Journal of European Social Policy, 16(1), 23-42.

Putnam, R. D. (2001). Bowling Alone: The Collapse and Revival of American Community. Simon and Schuster.

Sales, R. (2002). The Deserving and the Undeserving? Refugees, Asylum Seekers and Welfare in Britain. Critical Social Policy, 22(3), 456-478.

Sinclair, S., McKendrick, J. H., \& Kelly, P. (2009). Taking the High Road? Media and Public Attitudes Toward Poverty in Scotland. Scottish Affairs, 67(1), $70-91$.

Squire, V. (2008). Accounting for the Dominance of Control: Inter-Party Dynamics and Restrictive Asylum Policy in Contemporary Britain. British Politics, 3(2), 241-261. 
Squire, V. (2011). From Community Cohesion to Mobile Solidarities: The City of Sanctuary Network and the Strangers into Citizens Campaign. Political Studies, 59(2), 290-307.

Squire, V. (2016). The Exclusionary Politics of Asylum. Springer.

Statham, P., \& Geddes, A. (2006). Elites and the 'Organised Public': Who Drives British Immigration Politics and in Which Direction? West European Politics, 29(2), 248-269.

Temple, L., \& Grasso, M. T. (2017). Austerity, Politics, and Partisanship in the UK. In M. Giugni \& M. T. Grasso (Eds.), Citizens and the Crisis: Perceptions, Experiences, and Responses to the Great Recession in Europe. London: Palgrave Macmillan.

Temple, L., Grasso, M. T., Buraczynska, B., Karampampas, S., \& English, P. (2016). Neoliberal Narrative in Times of Economic Crisis: A Political Claims Analysis of the UK Press, 2007-2014. Politics \& Policy, 44(3), 553-576.

Thompson, E. P. (1963 [2016]). The Making of the English Working Class. Open Road Media.

Tonge, J. (2000). From Sunningdale to the Good Friday Agreement: Creating Devolved Government in Northern Ireland. Contemporary British History, $14(3), 39-60$.

Tonge, J. (2002). Northern Ireland: Conflict and Change. Pearson Education.

Torrance, D. (2013). The Battle for Britain. London: Biteback Publishing.

Van Oorschot, W., \& Arts, W. (2005). The Social Capital of European Welfare States: The Crowding Out Hypothesis Revisited. Journal of European Social Policy, 15(1), 5-26.

Verba, S., Schlozman, K. L., \& Brady, H. E. (1995). Voice and Equality: Civic Voluntarism in American Politics. Harvard University Press.

Wiggan, J. (2012). Telling Stories of 21st Century Welfare: The UK Coalition Government and the Neo-Liberal Discourse of Worklessness and Dependency. Critical Social Policy, 32(3), 383-405.

Wilcox, S. (2014). Housing Benefit Size Criteria: Impacts for Social Sector Tenants and Options for Reform. York: Joseph Rowntree Foundation. 
Open Access This chapter is licensed under the terms of the Creative Commons Attribution 4.0 International License (http://creativecommons.org/licenses/ by $/ 4.0 /$ ), which permits use, sharing, adaptation, distribution and reproduction in any medium or format, as long as you give appropriate credit to the original author(s) and the source, provide a link to the Creative Commons license and indicate if changes were made.

The images or other third party material in this chapter are included in the chapter's Creative Commons license, unless indicated otherwise in a credit line to the material. If material is not included in the chapter's Creative Commons license and your intended use is not permitted by statutory regulation or exceeds the permitted use, you will need to obtain permission directly from the copyright holder.

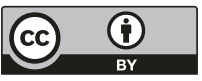

